\title{
DIRECTED SYNTHESIS OF POTENTIAL ANTITUMOR SUBSTANCES AMONG DERIVATIVES OF 3-MERCAPTO- 4-(PYRROL-1-YL)-5-CYCLOHEXYL-1,2,4-TRIAZOLE(4H)
}

\author{
N.B.Saidov, V.A.Georgiyants*, A.M.Demchenko** \\ Tajik National University, Dushanbe \\ * National University of Pharmacy, \\ 53, Pushkinska str., Kharkiv, 61002, Ukraine. E-mail: vgeor@ukr.net \\ ** Institute of Pharmacology and Toxicology, Kyiv
}

Key words: 3-mercapto-1,2,4-triazole; pyrrole; derivatives; synthesis; antitumor action

\begin{abstract}
Synthesis of the series of new 4-(1H-pyrrol-1-yl)-5-cyclohexyl-1,2,4-triazole(4H)-3-yl thioacetanilides from 4-amino-5-cyclohexyl-1,2,4-triazole(4H)-3-yl thioacetanilides previously synthesized is described. The target products 3a-z have been obtained by Paal-Knorre pyrrole condensation of the initial aminocompounds 1 with 2,5-dimethoxytetrahydrofuran (2) in the acetic acid medium. The structure of the substances synthesized has been proven by elemental analysis and NMR spectra data. All compounds synthesized contain signals of the cyclohexane system protons as two multiplets in their NMR spectra at 2.39-2.33 ppm (methyne proton) and 1.76-1.13 ppm (cyclohexyl methylene groups protons). Unlike the starting compounds (1) the end products (3a-z) have no signal of 4-aminogroup proton as a singlet in the spectra at 5.87-5.92 ppm. Instead of it, signals of the pyrrole ring are present as two triplets at 7-20-7.17 and 6.32-6.29 ppm. Among activities being more probable for the substances synthesized due to preliminary PASS-prognosis were inhibition of MAO and some enzymes $(P a=$ 0.554-0.729). Compound (3w) was selected by the National Cancer Institute (NCI) for in vitro screening on different tumour cell lines. As result of this investigation we have noted that, unfortunately, substance $3 w$ is not an effective inhibitor of tumour cells in the dose studied, in particular the growth percent for leukemia cells for more sensitive lines is 68.48 (RPMI-8226); 69.30 (HL-60(TB)); for non-small cell lung cancer - 63.06 (HOP-92); for melanoma - 47.82 (SK-MEL-5); 67.37 (UACC-62); for renal cancer - 56.66 (UO-31). Sensitivity of all cancer cell lines for the colon, CNS, ovarian, prostate and breast cancer was approximately at the control level.
\end{abstract}

ЦІЛЕСПРЯМОВАНИЙ СИНТЕЗ ПОТЕНЦІЙНИХ ПРОТИПУХЛИННИХ СУБСТАНЦІЙ В РЯДУ ПОХІДНИХ 3-МЕРКАПТО-4-(1Н-ПІРОЛ-1-ІЛ)-5-ЦИКЛОГЕКСИЛ-1,2,4-ТРИАЗОЛУ(4Н)

Н.Б.Саїдов, В.А.Георгіяни, А.М.Демченко

Ключові слова: 3-меркапто-1,2,4-триазол; пірол; похідні; синтез; протипухлинна дія

Описано синтез серії нових 4-(1Н-пірол-1-іл)-5-циклогексил-1,2,4-триазол(4Н)-3-ілтіоацетанілідів з одержаних раніше 4-аміно-5-циклогексил-1,2,4-триазол(4H)-3-іліоацетанілідів. Цільові речовини За-z отримані пірольною конденсацією Пааля-Кнорра з вихідних аміносполук 1 та 2,5-диметокситетрагідроффурану (2) в середовищі оцтової кислоти. Структура синтезованих речовин доведена за допомогою елементного аналізу і даних спектрів ЯМР ${ }^{1} \mathrm{H}$. Всі синтезовані сполуки містять у спектрах ЯМР ${ }^{1} \mathrm{H}$ сигнали системи циклогексанових протонів у вигляді двох мультиплетів при 2,39-2,33 м.ч. (метинові протони) та 1,76-1,13 м.ч. (протони метиленових груп циклогексилу). На відміну від вихідних сполук (1) кінцеві продукти (За-z) не мають у спектрах сигналу протона 4 - аміногрупи у вигляді синглету при 5, 87-5,92 м.4. Замість цього присутні сигнали протонів пірольного кільця у вигляді двох триплетів при 7-20-7.17 i 6.32-6.29 м.ч. Серед видів активності, які були найбільш ймовірні для синтезованих речовин відповідно до попереднього PASS-прогнозу, були інгібування MAO і деяких фрерментів (Pa = 0,554-0,729). Сполуку (3w) було обрано Національним інститутом раку (NCl) для скринінгу in vitro на різних лініях ракових клітин. У результаті цього дослідження ми відзначили, що речовина Зw, на жаль, не є ефективним інгібітором росту пухлинних клітин у досліджуваній дозі. Зокрема, відсоток росту лейкозних клітин для найбільш чутливих ліній був: 68,48 (RPMI-8226); 69,30 (HL-60 (TB)); для недрібноклітинного раку легенів - 63,06 (HOP-92); для меланоми - 47,82 (SK-MEL-5); 67,37 (UACC-62); для раку нирки - 56,66 (UO-31). Чутливість усіх ліній ракових клітин товстої кишки, ЦНС, яєчників, простати та молочної залози був приблизно на рівні контролю.

ЦЕЛЕНАПРАВЛЕННЫЙ СИНТЕЗ ПОТЕНЦИАЛЬНЫХ ПРОТИВООПУХОЛЕВЫХ СУБСТАНЦИЙ В РЯДУ ПРОИЗВОДНЫХ 3-МЕРКАПТО-4-(1Н-ПИРРОЛ-1-ИЛ)-5-ЦИКЛОГЕКСИЛ-1,2,4-ТРИАЗОЛА(4Н)

Н.Б.Саидов, В.А.Георгияни, А.М.Демченко

Ключевые слова: 3-меркапто-1,2,4-триазол; пиррол; производные; синтез; противоопухолевое действие Описан синтез серии новых 4-(1Н-пиррол-1-ил)-5-циклогексил-1,2,4-триазола(4Н)-3-илтиоацетанилидов из полученных ранее 4-амино-5-циклогексил-1,2,4-триазол(4Н)-3-илиоацетанилидов. Целевые вещества За-z получены пиррольной конденсацией Паля-Кнорра из исходных аминосоединений 1 и 2,5-диметокситетрагидрофурана (2) в среде уксусной кислоты. Структура синтезированных веществ доказана с помощью элементного анализа и данных спектров ЯМР $1 \mathrm{H}$. Все синтезированные соединения содержат в спектрах ЯМР ${ }^{1}$ Н сигналы системы циклогексановых протонов в виде двух мультиплетов при 2,39-2,33 м.д. (метиновые протоны) и 1,76-1,13 м.д (протоны метиленовых групп циклогексила). В отличие от исходных соединений (1) конечные продукты (За-z) не имеют в спектрах сигнала протона 4-аминогруппы в виде синглета при 5,87-5,92 м.д. Вместо этого присутствуют сигналы протонов пиррольного кольца в виде двух триплетов при 7-20-7.17 и 6.32-6.29 м.д. Среди видов активности, ко- 
торые были наиболее вероятны для синтезированных веществ в соответствии с предварительным PASS-прогнозом, было ингибирование MAO и некоторых ферментов $(P a=0,554-0,729)$. Соединение (3w) было выбрано Национальным институтом рака (NCl) для скрининга in vitro на различных линиях раковых клеток. В результате этого исследования мы отметили, что вещество Зw, к сожалению, не является эфрфективным ингибитором роста опухолевых клеток в изучаемой дозе. В частности, процент роста лейкозных клеток для наиболее чувствительных линий был: 68,48 (RPMI-8226); 69,30 (HL-60 (TB)); для немелкоклеточного рака легкого - 63,06 (HOP-92); для меланомы - 47,82 (SK-MEL-5); 67,37(UACC-62); для рака почки - 56,66 (UO-31). Чувствительность всех линий раковых клеток толстой кишки, ЦНС, яичников, простаты и молочной железы была примерно на уровне контроля.

In our present investigation a large group of alkylation products of 3-mercapto-4-amino-1,2,4-triazole $(4 \mathrm{H})$ has been synthesized [1]. Due to the presence of the aminogroup in their structure these substances possess a high hydrophility and have not a wide spectrum of the possible pharmacological activity. The main way for decreasing hydrophility for chemical substances is their chemical modification. We planned such modification of the aminogroup in compounds 1 basing on the literature data about the possible reactivity and products with the pharmacological activity. Thus, large series of compounds with a modified aminogroup are acylated [2], arylidene [3-6], thiosemicarbazide [7, 8] derivatives and products of their cyclization $[8,9]$. Mainly the substances synthesized have the antimicrobial activity.

For our investigation we planned to obtain chemical compounds with another structure. We have taken into account that combination in one molecule of both 1,2,4-triazole and pyrrole fragments is promissing for obtaining highly active substances with different kinds of the pharmacological activity [10-12]. It has been also noted that these substances possess the antitumour activity.

The abovementioned facts were prerequisites for planning modification of compounds $\mathbf{1}$ previously synthesized into the corresponding pyrrole derivatives 3 (Scheme).

For carrying out this synthesis we considered different possible methods of transformation of the aminogroup into the pyrrole cycle. The simplest way, in our opinion, is to use Paal-Knorr pyrrole condensation of 2,5-dimethoxytetrahydrofuran with amines, which usually allows to synthesize N-substituted pyrroles under very mild reaction conditions in good to excellent yields [13].

So, the end products 3a-y (Table 1) have been obtained by Paal-Knorre pyrrole condensation of the initial aminocompounds 1 with 2,5-dimethoxytetrahydrofuran 2 in the acetic acid medium. These conditions allow us to obtain substances 3 a-z with good yields and purity.

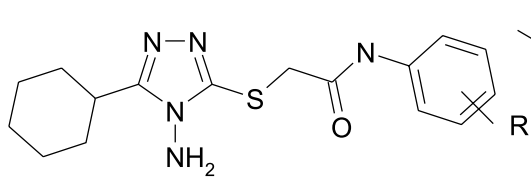

The structure of the substances synthesized has been proven by elemental analysis and NMR spectra data (Table 2).

All compounds synthesized contain signals of the cyclohexane system protons as two multiplets in their NMR spectra at 2.39-2.33 ppm (methyne protone) and 1.76-1.13 ppm (cyclohexyl methylene groups protones). Unlike the starting compounds (1) the end products (3a-z) have no signal of 4-aminogroup proton as a singlet in the spectra at 5.87-5.92 ppm [1]. Instead of it, signals of the pyrrole ring are present as two triplets at 7-20-7.17 and 6.32-6.29 ppm due to the presence of two pairs of magnet equivalent to methyne protons in the pyrrole structure. In some cases these signals overlap with aromatic protons of substituents signals interpreted in the correspondence with their intensity and multiplicity (Table 2). All spectra also contain singlets at 9.54-10.70 ppm due to presence of amide NH-protons.

Traditionally the preliminary prediction of the possible pharmacological activity by computer prognosis (PASS programme) [14] was used as the next step of our investigation for optimizing of the pharmacological screening.

Among activities, which are more probable for the substances synthesized, there is inhibition of MAO and some enzymes ( $\mathrm{Pa}=0.554-0.729)$. It should be noted that there is not enough information about structures like these ones.

Due to the prognosis and logical analysis data the substances synthesized have been examined as possible anticancer agents in vitro.

Of the compounds synthesized only one (3w) was selected by the National Cancer Institute (NCI) within the Developmental Therapeutic Programme (www.dtp.nci.nih.gov) for in vitro cell line screening. Anticancer assays were performed according to US NCI protocol [15]. The compound was evaluated in one dose in the primary anticancer assay towards approximately 60 cell lines (the concentration was $10^{-5} \mathrm{M}$ ). The human tumour cell lines represent all forms of cancer (such as non-small cell lung cancer, 
Table 1

Yields, melting points for the substances synthesized with the general formula of

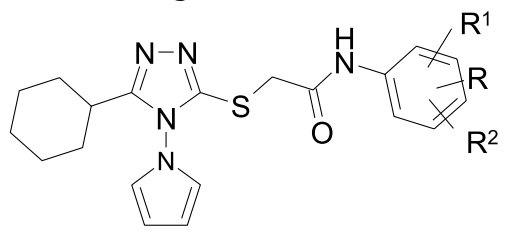

\begin{tabular}{|c|c|c|c|c|c|}
\hline Comp. & $\mathrm{R}$ & $\mathrm{R}^{1}$ & $\mathrm{R}^{2}$ & Yield & Melting point ${ }^{\circ} \mathrm{C}$ \\
\hline $3 \mathrm{a}$ & $3-\mathrm{Me}$ & $\mathrm{H}$ & $\mathrm{H}$ & 73.4 & $114-6$ \\
\hline $3 \mathrm{~b}$ & $2-\mathrm{Et}$ & $\mathrm{H}$ & $\mathrm{H}$ & 77.2 & $130-2$ \\
\hline $3 \mathrm{c}$ & $4-\mathrm{Et}$ & $\mathrm{H}$ & $\mathrm{H}$ & 81.1 & $134-6$ \\
\hline $3 \mathrm{~d}$ & $4-\mathrm{i}-\mathrm{Pr}$ & $\mathrm{H}$ & $\mathrm{H}$ & 74.4 & $138-40$ \\
\hline $3 \mathrm{e}$ & $2-\mathrm{OMe}$ & $\mathrm{H}$ & $\mathrm{H}$ & 76.5 & $118-20$ \\
\hline $3 \mathrm{f}$ & $3-\mathrm{Cl}$ & $\mathrm{H}$ & $\mathrm{H}$ & 70.8 & $125-7$ \\
\hline $3 \mathrm{~g}$ & $4-\mathrm{Cl}$ & $\mathrm{H}$ & $\mathrm{H}$ & 76.4 & $192-4$ \\
\hline $3 \mathrm{~h}$ & $3-\mathrm{F}$ & $\mathrm{H}$ & $\mathrm{H}$ & 77.8 & $148-50$ \\
\hline $3 \mathrm{i}$ & $4-\mathrm{F}$ & $\mathrm{H}$ & $\mathrm{H}$ & 80.5 & $158-60$ \\
\hline $3 \mathrm{j}$ & $3-\mathrm{CF}$ & $\mathrm{H}$ & $\mathrm{H}$ & 72.9 & $127-9$ \\
\hline $3 \mathrm{k}$ & $4-\mathrm{OEt}$ & $\mathrm{H}$ & $\mathrm{H}$ & 73.3 & $203-5$ \\
\hline $3 \mathrm{l}$ & $4-\mathrm{COOMe}$ & $\mathrm{H}$ & $\mathrm{H}$ & 75.7 & $218-20$ \\
\hline $3 \mathrm{~m}$ & $2-\mathrm{COOEt}$ & $\mathrm{H}$ & $\mathrm{H}$ & 77.6 & $135-7$ \\
\hline $3 \mathrm{n}$ & $4-\mathrm{COOEt}$ & $\mathrm{H}$ & $\mathrm{H}$ & 77.5 & $84-6$ \\
\hline $3 \mathrm{o}$ & $4-\mathrm{COMe}$ & $\mathrm{H}$ & $\mathrm{H}$ & 72.1 & $203-5$ \\
\hline $3 \mathrm{p}$ & $2-\mathrm{Me}$ & $3-\mathrm{Me}$ & $\mathrm{H}$ & 79.4 & $164-6$ \\
\hline $3 \mathrm{q}$ & $2-\mathrm{Me}$ & $5-\mathrm{Me}$ & $\mathrm{H}$ & 77.8 & $158-60$ \\
\hline $3 \mathrm{r}$ & $2-\mathrm{Me}$ & $5-\mathrm{Me}$ & $\mathrm{H}$ & 74.3 & $160-2$ \\
\hline $3 \mathrm{~s}$ & $3-\mathrm{Me}$ & $5-\mathrm{Me}$ & $\mathrm{H}$ & 75.5 & $156-8$ \\
\hline $3 \mathrm{t}$ & $2-\mathrm{Me}$ & $5-\mathrm{Cl}$ & $\mathrm{H}$ & 76.2 & $133-5$ \\
\hline $3 \mathrm{u}$ & $3-\mathrm{Me}$ & $4-\mathrm{Br}$ & $\mathrm{H}$ & 73.1 & $160-2$ \\
\hline $3 \mathrm{v}$ & $2-\mathrm{Me}$ & $4-\mathrm{Me}$ & $6-\mathrm{Me}$ & 83.3 & $166-8$ \\
\hline $3 \mathrm{w}$ & $2-\mathrm{OMe}$ & $4-\mathrm{OMe}$ & $\mathrm{H}$ & 77.6 & $116-8$ \\
\hline $3 \mathrm{x}$ & $3-\mathrm{OMe}$ & $4-\mathrm{OMe}$ & $\mathrm{H}$ & 73.8 & $168-70$ \\
\hline $3 \mathrm{y}$ & $2-\mathrm{Cl}$ & $6-\mathrm{Cl}$ & $\mathrm{H}$ & 71.7 & $220-2$ \\
\hline
\end{tabular}

colon cancer, breast cancer, ovarian cancer, leukemia, renal cancer, melanoma, prostate cancer). In the screening protocol, each cell line was inoculated and pre-incubated for 24-48 h on a microtiter plate. Test agents were then added at the single concentration and the culture was incubated for additional $48 \mathrm{~h}$. The end point determinations were made with a protein binding dye, sulforhodamine B (SRB). The results for each test agent were reported as the percent growth of the treated cells compared to the untreated control cells.

As result of this investigation we have noted that, unfortunately, substance $3 \mathrm{w}$ is not an effective inhibitor of tumour cells in the dose studied, in particular the growth percent for leukemia cells for more sensitive lines is 68.48 (RPMI-8226); 69.30 (HL-60(TB)); for non-small cell lung cancer - 63.06 (HOP-92); for melanoma - 47.82 (SK-MEL-5); 67.37 (UACC-62); for renal cancer - 56.66 (UO-31). Sensitivity of all cancer cell lines for the colon, CNS, ovarian, prostate and breast cancer was approximately at the control level.

The next step for investigation of these compounds will be the research of the CNS activity.

\section{Experimental Part}

Melting points were determined by the open capillary tube. NMR ${ }^{1} \mathrm{H}$ spectra were recorded on a Bruker WM spectrometer $(300 \mathrm{MHz})$; solvents $-\mathrm{CDCl}_{3}$ or DMSO- $\mathrm{d}_{6}$; chemical shifts were in $\mathrm{ppm}$, TMS was used as an internal standard. The purity of the compounds synthesized was monitored by TLC.

The elemental analysis data correspond to the calculated ones.

N-Phenyl-2-(5-cyclohexyl-4-(1H-1-pyrrolyl)-4H1,2,4-triazole-3-ylthio)acetanilides (3a-y, Table 1) (a general procedure). To the solution of 0.005 mole

Table 2

Chemical shifts $(\delta, p p m)$ at NMR ${ }^{1} \mathrm{H}$ spectra of the substances synthesized

\begin{tabular}{|c|c|c|c|c|c|c|c|c|}
\hline Comp. & $\begin{array}{c}\mathrm{NH}, \mathrm{s}, \\
1 \mathrm{H} \\
\end{array}$ & $\mathrm{Ar}-\mathrm{H}$ & $\begin{array}{c}\text { Pyrrole } \\
2.5,2 \mathrm{H}, \mathrm{t}\end{array}$ & $\begin{array}{l}\text { Pyrrole } \\
3.4,2 \mathrm{H}, \mathrm{t}\end{array}$ & $\begin{array}{l}\mathrm{S}-\mathrm{CH}_{2} \\
\mathrm{~s}, 2 \mathrm{H}\end{array}$ & $\begin{array}{c}\mathrm{CH}, \\
1 \mathrm{H}, \mathrm{m} \\
\end{array}$ & $5 \mathrm{xCH}_{2}$ (cyclohex), $10 \mathrm{H}, \mathrm{m}$ & Other \\
\hline 1 & 2 & 3 & 4 & 5 & 6 & 7 & 8 & 9 \\
\hline $3 a$ & 10.26 & \multicolumn{2}{|c|}{$\begin{array}{c}\text { 7.40, } 2 \mathrm{H}, \mathrm{m}, 7.19,3 \mathrm{H}, \mathrm{m} \\
6.90,1 \mathrm{H}, \mathrm{d}\end{array}$} & 6.31 & 4.10 & $\begin{array}{c}2.36,4 \mathrm{H} \\
\left(+\mathrm{CH}_{3}\right) \\
\end{array}$ & $1.76-1.16$ & - \\
\hline $3 b$ & 9.69 & \multicolumn{2}{|c|}{$7.35,1 \mathrm{H}, \mathrm{d}, 7.18,5 \mathrm{H}, \mathrm{m}$} & 6.31 & 4.13 & 2.36 & $1.76-1.16$ & $\begin{array}{c}2.57,2 \mathrm{H}, \mathrm{KB}, \mathrm{CH}_{2} \mathrm{CH}_{3 \prime} \\
\quad 1.11,3 \mathrm{H}, \mathrm{C}, \mathrm{CH}_{3}\end{array}$ \\
\hline $3 c$ & 10.27 & \multicolumn{2}{|c|}{$7.48,2 \mathrm{H}, \mathrm{d}, 7.19,4 \mathrm{H}, \mathrm{m}$} & 6.31 & 4.10 & 2.35 & $1.75-1.15,13 \mathrm{H}, \mathrm{m}\left(\mathrm{CH}_{3}\right)$ & $2.51,2 \mathrm{H}, \mathrm{C}, \mathrm{CH}_{2}$ \\
\hline $3 d$ & 10.26 & \multicolumn{2}{|c|}{$7.45,2 \mathrm{H}, \mathrm{d}, 7.17,4 \mathrm{H}, \mathrm{m}$} & 6.31 & 4.09 & 2.36 & $1.75-1.16,16 \mathrm{H}, \mathrm{M}\left(+2 \times \mathrm{CH}_{3}\right)$ & $2.84,1 \mathrm{H}, \mathrm{C}, \mathrm{CH}$ \\
\hline $3 e$ & 9.67 & $\begin{array}{c}\text { 7.97, } 1 \mathrm{H}, \mathrm{d}, 7.06,1 \mathrm{H}, \mathrm{m}, \\
6.91,1 \mathrm{H}, \mathrm{t} \\
\end{array}$ & 7.20 & 6.31 & 4.14 & 2.35 & $1.76-1.16$ & $3.32,3 \mathrm{H}, \mathrm{s}, \mathrm{OCH}_{3}$ \\
\hline $3 f$ & 10.62 & $7.09 ; 7.38-7.54, \mathrm{~m}, 4 \mathrm{H}$ & 7.18 & 6.30 & 4.11 & 2.39 & $1.72-1.17$ & \\
\hline $3 g$ & 10.41 & \multicolumn{2}{|c|}{$\begin{array}{c}8.65,1 \mathrm{H}, \mathrm{d}, 7.95,1 \mathrm{H}, \mathrm{d}, 7.63,1 \mathrm{H}, \mathrm{t} \\
7.20,3 \mathrm{H}, \mathrm{m}\end{array}$} & 6.32 & 4.11 & 2.34 & $1.73-1.17,13 \mathrm{H}\left(+\mathrm{CH}_{3}\right)$ & $4.31,2 \mathrm{H}, \mathrm{q}, \mathrm{CH}_{2} \mathrm{CH}_{3}$ \\
\hline $3 \mathrm{~h}$ & 10.56 & $\begin{array}{c}\text { 7.57, } 1 \mathrm{H}, \mathrm{d}, 7.36,2 \mathrm{H}, \mathrm{m}, \\
6.91,1 \mathrm{H}, \mathrm{t}\end{array}$ & 7.20 & 6.32 & 4.13 & 2.36 & $1.75-1.15$ & - \\
\hline $3 i$ & 10.41 & \multicolumn{2}{|c|}{$7.59,2 \mathrm{H}, \mathrm{m}, 7.19,4 \mathrm{H}, \mathrm{m}$} & 6.31 & 4.10 & 2.36 & $1.73-1.14$ & - \\
\hline $3 j$ & 10.71 & $8.06-7.44,4 \mathrm{H}, \mathrm{m}$ & 7.20 & 6.32 & 4.14 & 2.34 & $1.71-1.15$ & - \\
\hline $3 k$ & 10.18 & $7.45 ; 6.87, \mathrm{dd}, 4 \mathrm{H}$ & 7.18 & 6.30 & 4.07 & 2.34 & $1.74-1.15,13 \mathrm{H}\left(+\mathrm{CH}_{3}\right)$ & $3.96,2 \mathrm{H}, \mathrm{q}, \mathrm{OCH}_{2}$ \\
\hline
\end{tabular}


Table 2 continued

\begin{tabular}{|c|c|c|c|c|c|c|c|c|}
\hline 1 & 2 & 3 & 4 & 5 & 6 & 7 & 8 & 9 \\
\hline 31 & 10.67 & $7.93,2 \mathrm{H}, \mathrm{d}, 7.70,2 \mathrm{H}, \mathrm{d}$ & 7.17 & 6.29 & 4.14 & 2.35 & $1.74-1.16$ & $3.81, \mathrm{~s}, 3 \mathrm{H}\left(\mathrm{OCH}_{3}\right)$ \\
\hline $3 m$ & 11.20 & $7.50,2 \mathrm{H}, \mathrm{m}, 7.35,1 \mathrm{H}, \mathrm{m}$ & 7.19 & 6.31 & 4.10 & 2.35 & $1.73-1.15$ & $2.31,3 \mathrm{H}, \mathrm{s}, \mathrm{CH}_{3}$ \\
\hline $3 n$ & 10.64 & $7.93,2 \mathrm{H}, \mathrm{d}, 7.70,2 \mathrm{H}, \mathrm{d}$ & 7.17 & 6.30 & 4.13 & 2.35 & $1.74-1.16,13 \mathrm{H}\left(+\mathrm{CH}_{3}\right)$ & $4.28,2 \mathrm{H}, \mathrm{q}, \mathrm{CH}_{2} \mathrm{CH}_{3}$ \\
\hline 30 & 10.69 & $7.94,2 \mathrm{H}, \mathrm{д}, 7.72,2 \mathrm{H}, \mathrm{д}$ & 7.19 & 6.31 & 4.16 & 2.35 & $1.76-1.15$ & $2.51,3 \mathrm{H}, \mathrm{C}, \mathrm{CH}_{3}$ \\
\hline $3 p$ & 9.74 & $7.14,1 \mathrm{H}, \mathrm{d}, 6.04,2 \mathrm{H}, \mathrm{m}$ & 7.20 & 6.32 & 4.11 & 2.36 & $1.75-1.17$ & $\begin{array}{c}2.25,3 \mathrm{H}, \mathrm{C} \\
2.07,3 \mathrm{H}, \mathrm{s}, 2 \times \mathrm{CH}_{3}\end{array}$ \\
\hline $3 q$ & 9.61 & $7.05, \mathrm{~m}, 3 \mathrm{H}$ & 7.18 & 6.31 & 4.11 & 2.35 & $1.75-1.16$ & $2.49,6 \mathrm{H}, \mathrm{s}, 2 \times \mathrm{CH}_{3}$ \\
\hline $3 r$ & 9.64 & $\begin{array}{c}7.23,1 \mathrm{H}, \mathrm{c}, 7.08,1 \mathrm{H}, \mathrm{d} \\
6.89,1 \mathrm{H}, \mathrm{d} \\
\end{array}$ & 7.18 & 6.30 & 4.09 & 2.35 & $1.75-1.15$ & $\begin{array}{c}2.49,3 \mathrm{H}, \mathrm{C} \\
2.13,3 \mathrm{H}, \mathrm{s}, 2 \mathrm{xCH}_{3} \\
\end{array}$ \\
\hline $3 \mathrm{~s}$ & 10.17 & \multicolumn{2}{|c|}{$7.17,4 \mathrm{H}, \mathrm{m}, 6.72,1 \mathrm{H}, \mathrm{c}$} & 6.29 & 4.08 & 2.35 & $1.76-1.16$ & $2.18, \mathrm{c}, 6 \mathrm{H}, \mathrm{CH}_{3}$ \\
\hline $3 t$ & 9.72 & \multicolumn{2}{|c|}{$7.59,1 \mathrm{H}, \mathrm{s}, 7.19,4 \mathrm{H}, \mathrm{m}$} & 6.31 & 4.12 & 2.35 & $1.73-1.16$ & $2.20,3 \mathrm{H}, \mathrm{s}, \mathrm{CH}_{3}$ \\
\hline $3 u$ & 10.41 & $7.50,2 \mathrm{H}, \mathrm{m}, 7.35,1 \mathrm{H}, \mathrm{m}$ & 7.19 & 6.31 & 4.10 & 2.35 & 1.73-1.15 & $2.31,3 \mathrm{H}, \mathrm{s}, \mathrm{CH}_{3}$ \\
\hline $3 v$ & 9.53 & $6.86,2 \mathrm{H}, \mathrm{s}$ & 7.18 & 6.31 & 4.09 & 2.36 & $1.73-1.15$ & $\begin{array}{c}2.21,3 \mathrm{H}, \mathrm{C} \\
2.06,3 \mathrm{H}, \mathrm{s}, 2 \mathrm{xCH}_{3}\end{array}$ \\
\hline $3 w$ & 9.51 & $\begin{array}{c}7.76,1 \mathrm{H}, \mathrm{d}, 6.61,1 \mathrm{H}, \mathrm{s}, \\
6.41,1 \mathrm{H}, \mathrm{d}\end{array}$ & 7.19 & 6.31 & 4.09 & 2.33 & $1.73-1.13$ & $\begin{array}{c}3.81,3 \mathrm{H}, \mathrm{C} \\
3.74,3 \mathrm{H}, \mathrm{s}, 2 \times \mathrm{CH}_{3} \\
\end{array}$ \\
\hline $3 x$ & 10.20 & \multicolumn{2}{|l|}{$7.28-7.19,5 \mathrm{H}, \mathrm{m}$} & 6.32 & 4.08 & 2.35 & $1.76-1.16$ & $2.71,6 \mathrm{H}, \mathrm{c}, 2 \mathrm{xOCH}_{3}$ \\
\hline $3 y$ & 10.28 & $7.54, \mathrm{~d} ; 2 \mathrm{H}, 7.35, \mathrm{t}, 1 \mathrm{H}$ & 7.17 & 6.30 & 4.16 & 2.34 & $1.73-1.15$ & - \\
\hline
\end{tabular}

of N-phenyl-2-(4-amino-5-cyclohexyl-4H-1,2,4-triazol3 -ylthio)acetanilide 2 [1] in $40 \mathrm{ml}$ acetic acid add 0.005 mole of 2,5-dimethoxytetrahydrofurane. Reflux the reaction mixture for about $1 \mathrm{~h}$, cool and place into $200 \mathrm{ml}$ water. Collect and dry the precipitate recrystallizing it from ethanol.

\section{Conclusions}

1. Series of new N-Phenyl-2-(5-cyclohexyl-4-(1H1-pyrrolyl)-4H-1,2,4-triazole-3-ylthio)acetanilides has been synthesized started from the corresponding amino derivatives using Paal-Knorr condensation. The structure of the compounds synthesized has been proven by elemental analysis and NMR-spectra data.

2. Due to prognosis and logical analysis data the pharmacological screening have been planed for discovering of an antitumour and CNS-agent. It has been shown that in the in-vitro investigation one of the compounds synthesized has not a high potential in the cancer cell inhibition.

\section{References}

1. Saidov N. B., Georgiyants V. A., Garna N. V. Zhurnal organichnoi ta farmacevtichnoi khimii - Journal of organic and pharmaceutical chemistry, 2013, Vol. 11, 4(44), pp.33-37.

2. Upmanyu N., Kumar S., Murali-Dhar, Kharya, Shah K., Mishra P. Acta Poloniae Pharmaceutica. Drug Research, 2011, Vol. 68, 2, pp.212-221.

3. Goyal P. K., Bhandari A., Rana A. C., Jain C. B. International Journal Chem. Tech. Research, 2010, Vol. 2, 4, pp.1992-1997.

4. Jubie S., Sikdar P., Kalirajan R., Kalirajan R., Gowramma B., Gomathy S., Elango K. Pakistan Journal Pharmaceutical Research, 2011, Vol. 3, 3, pp.511-513.

5. Calisir M. M., Kocyigit-Kaymakcioglu B., Uzbek B., Utuk G. E-Journal of Chemistry, 2010, Suppl. 1, Vol. 7, pp.458-464.

6. Valentina P., Ilango K., Deepthi M., Harusha P., Pavani G. Journal of Pharmaceutical Sciences and Research, 2009 , Vol. 1, 2, pp.74-77.

7. Kshirsagar A., Toraskar M. P., Kulkarni V., Dhanashirez M. S., Kadam V. International Journal Chem. Tech. Research, 2009, Vol. 1, 3, pp.696-701.

8. Al-Omar M. A. Molecules, 2010, Vol. 15, pp.502-514.

9. Bhat K. S., Poojary B., Prasad D. J., Naik P., Holla B. S. European Journal of Medicinal Chemistry, 2009, Vol. 44, 12, pp.5066-5070.

10. Idhayadhulla A., Kumar R. S., Nasser A. J. A., Manilal A. Der Pharma Chemica, 2011, Vol. 3, 4, pp.210-218.

11. Joshi S. D., More U. A., Kulkarni V. H. Indian Journal of Pharmaceutical Sciences, 2013, Vol. 75, 3, pp.310-323.

12. Bijev A. T., Prodanova P. Khimia geterociklicheskih soedinenij-Chemistry of Heterocyclic Compounds, 2007, Vol. 43, 3, pp.306-313.

13. Azizi N., Khajeh-Amiri A., Ghafuri H., Bolourtchian M., Saidi M. R. Synlett, 2009, pp.2245-2248.

14. Poroikov V. V. Medicinal Chemistry Research, 2010, Vol. 19 (S1). pp.30.

15. Shoemaker R. H. Nature Reviews Cancer, 2006, Vol. 6, pp.813-823.

Надійшла до редакції 05.02.2014 p. 